\title{
Pancreatic duodenal homeobox factor-1 and diabetes mellitus type 2 (Review)
}

\author{
FAIZEH AL-QUOBAILI ${ }^{1,2}$ and MATHIAS MONTENARH ${ }^{1}$ \\ ${ }^{1}$ Medical Biochemistry and Molecular Biology, University of the Saarland, D-66424 Homburg, Germany; \\ ${ }^{2}$ Department of Biochemistry and Microbiology, Faculty of Pharmacy, Damascus University, 6735 Damascus, Syria
}

Received October 3, 2007; Accepted December 3, 2007

\begin{abstract}
The homeobox domain transcription factor PDX-1 is essential for pancreatic development and for the maintenance of $ß$-cell function. The participation of pancreatic duodenal homeobox factor-1 (PDX-1) in the transcription of several genes which are essential for glucose sensing and insulin synthesis underlines its key role in B-cells of the pancreas. PDX-1 binds to the promoter of insulin, glucose transporter 2, and glucokinase and regulates their expression. By proteinprotein interaction, PDX-1 acts in concert with other transcription factors or coactivators at the level of the insulin promoter. Ectopic expression of PDX-1 together with other cofactors can re-program cells to behave like $\beta$-cells and produce insulin. This property of PDX-1 opens new strategies for the treatment of diabetes. Little is known about its regulation at the posttranslational level. Here, we report on its DNA-binding activity, the nuclear import and on posttranslational modifications such as phosphorylation, glycosylation and sumoylation. Modulation of these posttranslational modifications may be an alternate strategy for treating diabetes.
\end{abstract}

\section{Contents}

1. Introduction

2. The role of PDX-1 in diabetes mellitus type 2

3. Molecular aspects of the PDX-1 protein

4. Concluding remarks

\section{Introduction}

Diabetes mellitus is a heterogeneous metabolic disease, which is characterized by persistent hyperglycaemia resulting from

Correspondence to: Dr Mathias Montenarh, Medical Biochemistry and Molecular Biology, University of the Saarland, Building 44, D-66424 Homburg, Germany

E-mail: montenarh@uks.eu

Key words: homeobox factor-1, diabetes mellitus type 2, insulin defects in insulin production, insulin action or both. In 2006, according to the World Health Organization, at least 171 million people worldwide were suffering from diabetes, and it is estimated that by the year 2030, this number will double. As in many other countries of the world, Syria with its 16 million inhabitants has witnessed a tremendous change in nutritional habits and lifestyle during the last few decades. This has been reflected in an increase in metabolic diseases in general and diabetes in particular. The prevalence of diabetes in Syria is $\sim 10 \%$, which is comparable to the percentage found in neighbouring countries such as in Lebanon (13\%), Egypt (6\%), and Tunisia (9\%) where an enormous increase is also expected within the next few years (1). Diabetes can be associated with serious complications if not diagnosed early in life, and when not treated properly diabetes mellitus leads to blindness, dysfunction of the kidneys and the peripheral nervous system, microvascular damage and in general to a reduced life expectancy. Symptoms of diabetes are polyuria (frequent urination), polydipsia (increased thirst and consequent increased fluid intake) and polyphagia (increased appetite), although weight loss may occur. The complications of diabetes are far less common and less severe in people who have well controlled blood sugar levels $(2,3)$. There are three major types of diabetes: type 1, type 2 and gestational diabetes (occurring during pregnancy) $(4,5)$, which have similar symptoms and consequences, but different causes and population distributions. Type 1 diabetes, previously known as insulin-dependent diabetes (IDDM), childhood diabetes or also known as juvenile diabetes, is an auto-immune disease, due to destruction of the insulin-producing $\beta$-cells in the pancreas. Type 1 diabetes accounts for $10-15 \%$ of people with the disease. It appears to be triggered by certain (mainly viral) infections, diet or chemicals in people genetically predisposed. Type 2 diabetes mellitus, previously known as adult-onset diabetes or non-insulin-dependent diabetes mellitus (NIDDM), is the most common form of diabetes accounting for $90 \%$ of all cases of diabetes mellitus. Moreover, between 10 and $20 \%$ of individuals older than 45 years of age in developed countries suffer from this form of diabetes, and the largest number is found in those aged 65 years and over, while in developing countries the largest number of people with this diabetes are in the age group 45 to 64 years. Worldwide rates are similar for men and women (6). Type 2 diabetes is becoming increasingly common in children (7). Type 2 diabetes is characterized by varying degrees of insulin resistance and $\beta$-cell dysfunction 
leading to hyperglycaemia. Gestational diabetes mellitus (GDM) develops during pregnancy and may improve or disappear after delivery. It resembles type 2 diabetes on several respects. Risk factors for GDM include a family history of diabetes, increasing maternal age, obesity and being a member of an ethnic group with a high risk of developing type 2 diabetes (8). There are other rare forms of diabetes that are directly inherited. These include diabetes due to mutations in mitochondrial DNA, genetically related insulin resistance and diseases of the pancreas (e.g. cystic fibrosis) (9). Other specific types of diabetes result from surgery, drugs, malnutrition, infections and other illnesses. Such types of diabetes may account for no more than $5 \%$ of all diagnosed cases.

The major environmental risk factors for type 2 diabetes are obesity (body mass index $>30 \mathrm{~kg} / \mathrm{m}^{2}$ ) and a sedentary lifestyle $(10,11)$. Type 2 diabetes is diagnosed upon a fasting plasma glucose concentration $>7.0 \mathrm{mmol} / 1$ (126 mg/ dl) or with a glucose tolerance test, $2 \mathrm{~h}$ after the oral dose of a plasma glucose $>11.1 \mathrm{mmol} / 1$ (200 mg/dl) (12). Type 2 diabetes is manifested as the body develops a resistance to insulin and no longer uses the insulin properly. As the need for insulin rises, the pancreas gradually loses its ability to produce sufficient amounts of insulin to regulate blood sugar. Regulation of insulin gene expression in response to an increase in blood glucose levels is essential for maintaining normal glucose homeostasis.

The required insulin level is tightly and cooperatively regulated by transcription factors, nutrients and hormones. The islet of Langerhans is the functional section of the endocrine pancreas where the insulin-producing $\beta$-cells represent the majority of the endocrine cell population. In addition $\alpha, \delta$ and pancreatic polypeptide $\mathrm{PP}(\mathrm{F})$ cells are found in the islets which produce glucagon, somatostatin and PP, respectively. Pancreatic B-cells act as glucose sensors and simultaneously integrate different signals to synthesize and secret insulin. Glucose enters the B-cells through glucose transporter 2 (GLUT2) and is then phosphorylated by glucokinase to produce glucose-6-phosphate. Both GLUT2 and glucokinase expression is regulated by a transcription factor called PDX-1. In $\delta$ cells PDX-1 regulates the expression of somatostatin $(13,14)$. In addition to $ß$-cells, $\delta$ cells also express PDX-1.

\section{The role of PDX-1 in diabetes mellitus type 2}

Among the several molecular events which are implicated in the manifestation of diabetes mellitus, mutations in genes whose gene products affect the ability of $\beta$-cells to secrete insulin play an essential role. In rare forms of diabetes, mutations of only one gene can result in disease. However, in type 2 diabetes many genes are thought to be involved (15). Among those genes which are expressed in $\beta$-cells of the pancreas is the pancreatic duodenal homeobox factor- 1 (PDX-1) which is also known as IDX-1, STF-1 and Igf-1. In this review we will use the abbreviation PDX-1. The human PDX-1 gene is located on chromosome 13q 12.1. It consists of two exons spanning a region of $\sim 6 \mathrm{~kb}$ (16). Although mutations in the PDX-1 gene are rare, all of the known mutations affect transcription of the insulin gene with an impaired response to elevated levels of glucose $(17,18)$.
Mutations in the PDX-1 gene lead to a decrease in the binding activity of PDX-1 protein to the insulin promoter which is accompanied by reduced transcription of insulin in response to hyperglycaemia (19).

The early-onset type 2 diabetes mellitus which is also called maturity-onset diabetes of the young (MODY 4), is clearly linked to an inactivating mutation in the PDX-1 gene $(20,21)$. In addition to the regulation of the expression of insulin, PDX-1 also regulates early pancreatic development $(22,23)$. Targeted disruption of the PDX-1 gene in mice results in abnormalities of the pancreas. Jonsson et al $(24,25)$ reported that mice homozygous for the PDX-1 deletion selectively lacked a pancreas at birth. In a $\beta$-cell-specific knockout of the PDX-1 gene, mice developed an adult-onset, non-insulin-resistant type of diabetes (26). These models further support the notion that mutations in the PDX-1 gene contribute to the development of type 2 diabetes in humans. Furthermore, pancreas abnormalities are connected with an inactivating mutation in exon 1 of PDX-1 (21). In addition, a heterozygote with a frame-shift mutation within the PDX-1 gene coding region, which resulted in a truncated, nonfunctional protein, has been identified in children born with pancreatic agenesis $(23,27)$.

During organogenesis PDX-1 is widely expressed in all cells differentiating into the exocrine and endocrine components of the pancreas whereas in the mature pancreas PDX-1 expression is predominantly restricted to the insulinproducing islet $B$-cells. The replacement of islet cells is considered to be the optimal treatment for type 1 diabetes mellitus. However the availability of human islet cells for transplantation is rather limited. Ferber et al reported that ectopic expression of PDX-1 in liver cells could re-program the hepatic tissues to pancreatic $\beta$-cell characteristics with a secretion of insulin (28). It was recently shown that human bone marrow-derived mesenchymal stem cells could be induced to differentiate into functional insulin-producing cells by introduction of PDX-1 (29). Thus, these results show that PDX-1 has the capacity to re-program extra pancreatic tissue towards a $ß$-cell phenotype and function. This observation was later confirmed by different groups using adenoviral vector constructs for gene transfer (30-32).

Differentiation of embryonic stem (ES) cells into insulinsecreting cells is an additional technique being promoted for the future therapeutic treatment of diabetes mellitus. It was previously shown that a synergistic expression of PDX-1 and NeuroD1 which is known to be regulated downstream of neurogenin 3 is sufficient for the maintenance of the properties of insulin-producing cells derived from ES cells $(33,34)$. Furthermore, adult tissue cells from the liver, intestinal epithelium-derived cells, and certain populations of bone marrow cells were shown to have the potential to differentiate into insulin-producing cells with the help of PDX-1 (Fig. 1) (35-37). Thus, these experiments provide the potential for the treatment of diabetes mellitus.

At the level of the insulin gene promoter, PDX-1 interacts with other proteins such as $\beta 2 / \mathrm{NeuroD} 1, \mathrm{E} 47 / \mathrm{Pan} 1$, the high mobility group protein I (38), the p300 coactivator (39) and Bridge-1 (40). The region of the insulin gene promoter to which PDX-1 binds is essential for regulation of insulin gene expression (41). Histone H4 acetylation plays an important 


\section{PDX-1 and re-programming of cells and tissue}

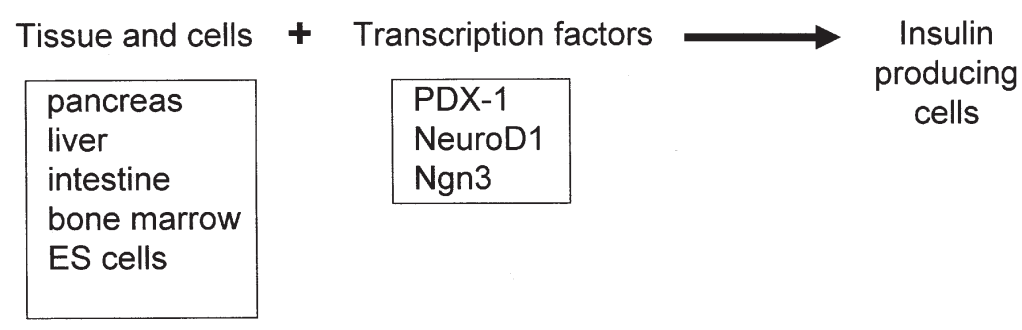

Figure 1. PDX-1 and re-programming of cells and tissue. Transfection of embryonic stem (ES) cells and cells from different organs with PDX-1 and other transcription factors such as NeuroD1 and neurogenin 3 (Ngn3) leads to insulin-producing cells.

\section{PDX-1}
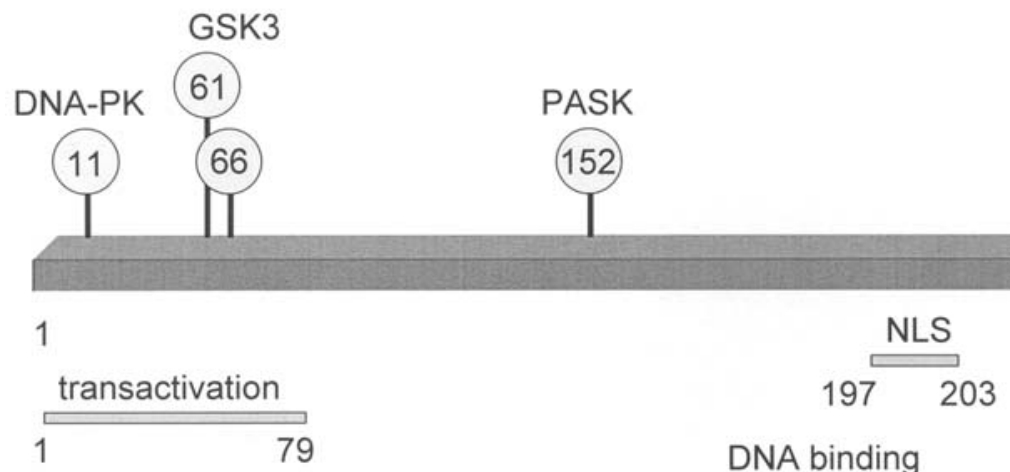

DNA binding
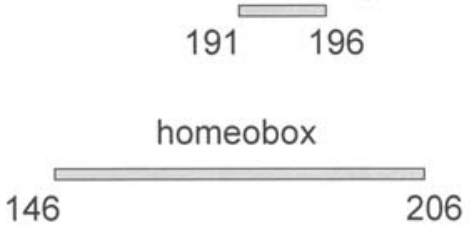

Antennapedia domain

188 203

Figure 2. Functional domains and phosphorylation sites of PDX-1. Schematic drawing of the 283-amino acid-long PDX-1 protein with functional domains and known phosphorylation sites. The numbers indicate the phosphorylated residues on the polypeptide chain of PDX-1 or the borders of the functional domains. NLS, nuclear localization signal; GSK, glycogen synthase kinase 3; PASK, Per-Arnt-Sim kinase.

role in regulated gene expression (42). Glucose-mediated hyperacetylation of histone $\mathrm{H} 4$ depends on the recruitment of the histone acetyltransferase p300 by PDX-1 (43). PDX-1 regulates insulin expression under low and high concentrations of glucose. Upon high glucose concentrations, PDX-1 mediates hyperacetylation of histone $\mathrm{H} 4$ and increases insulin gene expression. Upon low glucose concentrations, PDX-1 interacts with the histone deacetylases HDAC-1 and HDAC-2, which causes deacetylation of histone $\mathrm{H} 4$ and the downregulation of insulin gene expression. PDX-1 becomes phosphorylated at different residues depending on the concentration of glucose, which may determine its interaction with p300 or HDAC-1/2. This observation was further supported by experiments where cells were treated with okadaic acid which inhibits dephosphorylation of PDX-1. Okadaic acid treatment enables PDX-1 to bind efficiently to the histone acetyltransferase p300 (44).

Low concentrations of insulin have an apoptosis-preventing activity. It was demonstrated that this antiapoptotic activity is mediated directly by PDX-1. Insulin stimulates the DNAbinding activity of PDX-1 in human islet cells (45), and it stimulates a modest and transient increase in the PDX-1 protein expression (46).

Although it is clear that PDX-1 functions as a transcription factor, there is some indication that PDX-1, probably with corepressor molecules, might also repress genes such as glucagon $(26,47)$. 


\section{Molecular aspects of the PDX-1 protein}

The PDX-1 gene codes for a protein with 283 amino acids. The PDX-1 protein sequence is very homologous among different species. The N-terminus contains the transactivation domain. The middle region contains a homeodomain, which is responsible for DNA binding and protein-protein interactions as a transcriptional activation mechanism. The role of the C-terminus is poorly understood. There are indications that the C-terminus has an inhibitory function whereas other data show that the $\mathrm{C}$-terminus is required for full transactivation $(17,48,49)$. The $\mathrm{C}$-terminus harbours an evolutionarily conserved region, which mediates the interaction with the PDX C-terminus interacting factor-1 (PCIF-1). PCIF-1 inhibits PDX-1 transactivation in a specific and dose-dependent manner supporting the view that the $\mathrm{C}$ terminus is necessary for transactivation. The polypeptide chain contains a nuclear localization signal (NLS) consisting of seven amino acids (RRMKWKK) that is conserved in mice, rats and humans. In the middle part of the protein is a proline-rich domain, which is implicated in the heterodimerization with the DNA-binding protein PBX-1 (50). Liu et al (51) suggested that PBX-1, a member of the TALE (3 amino acid loop extension) class of homeodomain transcription factors, is essential for normal development and function of the pancreas. Furthermore, PBX-1 and PDX-1 form a complex that regulates the somatostatin (SST) gene transcription cooperatively (52). It is possible that through its interactions with PDX-1, PBX-1 may play an important role in the early developmental stage of the pancreas (53).

Within the homeobox domain, PDX-1 contains an Antennapedia-like domain which allows it to permeate into cells (54). The Antennapedia sequence includes the abovementioned nuclear localization signal $(55,56)$ and a sequence motif KIWFQN which seems to be important for its DNAbinding activity (Fig. 2) (49).

At low glucose concentrations PDX-1 protein localizes exclusively in the cytoplasm. Incubation of islets with high glucose concentrations results in a rapid translocation of PDX-1 to the nucleus. Overexpression experiments with stress-activated protein kinase 2 (SAPK2) as well as inhibition studies with SB203580, a specific inhibitor of SAPK2, revealed that glucose regulates the insulin gene promoter through activation and nuclear translocation of PDX-1 via the SAPK2 pathway $(57,58)$. Wortmannin, a PI3 kinase inhibitor, also inhibits the glucose- or insulinstimulated nuclear translocation of PDX-1 (59). The inactive cytoplasmic form of PDX-1 migrates at a molecular weight of $31 \mathrm{kDa}$ whereas the nuclear-activated form migrates more slowly at $46 \mathrm{kDa}$. Phosphorylation may induce a conformational change in PDX-1 which affects its mobility on SDSpolyacrylamide gels. It was further shown that PDX-1 is modified by SUMO-1 (small ubiquitin-related modifier 1), which may be responsible for the increase in molecular mass by $\sim 15 \mathrm{kDa}$. The sumoylated PDX-1 is located in the nucleus and is found to be more stable than the non-sumoylated form (60).

Glycogen synthase kinase 3 (GSK3) is a ubiquitously expressed serine/threonine kinase, which is constitutively active in resting cells and is inactivated by insulin. It was recently shown that PDX-1 is phosphorylated in vivo on serine 61 and/or serine 66 in pancreatic B-cells by GSK3, and this phosphorylation targets the protein for degradation by the proteasome (61). It was also clear from this study that serine 61 and/or serine 66 phosphorylation do not modulate PDX-1 activity.

PDX-1 is also posttranslationally modified by O-linked $\mathrm{N}$-acetylglucosamine (62). Furthermore, an elevated glucose concentration leads to an increase in glycosylation which correlates with an increase in DNA-binding activity of PDX-1 and insulin secretion of $\beta$-cells. Mass spectrometry analysis revealed that PDX-1 interacts with the two regulatory subunits of the kinase DNA-PK namely Ku70 and Ku80. PDX-1 is not only a binding partner for subunits of DNA-PK but is also phosphorylated by DNA-PK at least in vitro. After $\gamma$-radiation PDX- 1 is phosphorylated at threonine 11 by DNA-PK and is then rapidly degraded. This degradation proceeds with a rapid reduction in the activation of the insulin promoter and a decrease in the expression of GLUT2 and glucokinase (63). Per-Arnt-Sim kinase (PASK) is another enzyme which phosphorylates PDX-1 at least in vitro at threonine 152. By using point mutations at this position, it was found that phosphorylation at threonine 152 inhibits nuclear uptake of PDX-1 in response to elevated glucose concentrations (64).

\section{Concluding remarks}

The functions of the PDX-1 gene and protein have been extensively studied. There is promising progress in redirecting various cell types to behave like $\beta$-cells and to produce insulin. However, the knowledge concerning posttranslational modifications of the PDX-1 protein and its interaction with other regulatory proteins is at the onset. The knowledge of the proteomic properties of PDX-1 is essential in order to develop new strategies for the treatment of diabetes mellitus.

\section{References}

1. Albach N: Epidemiological studies lay the ground for Syrian diabetes campaign. Diabetes Voice 46: 18-21, 2001.

2. Nathan DM, Cleary PA, Backlund JY, Genuth SM, Lachin JM, Orchard TJ, Raskin P and Zinman B: Intensive diabetes treatment and cardiovascular disease in patients with type 1 diabetes. N Engl J Med 353: 2643-2653, 2005.

3 . The effect of intensive diabetes therapy on the development and progression of neuropathy. The Diabetes Control and Complications Trial Research Group. Ann Intern Med 122: 561-568, 1995.

4. Salsali A and Nathan M: A review of types 1 and 2 diabetes mellitus and their treatment with insulin. Am J Ther 13: 349-361, 2006.

5. Hunt KJ and Schuller KL: The increasing prevalence of diabetes in pregnancy. Obstet Gynecol Clin North Am 34: 173-199, 2007.

6. Sarafidis PA, McFarlane SI and Bakris GL: Gender disparity in outcomes of care and management for diabetes and the metabolic syndrome. Curr Diab Rep 6: 219-224, 2006.

7. Bloomgarden ZT: Type 2 diabetes in the young: the evolving epidemic. Diabetes Care 27: 998-1010, 2004.

8. Silva JK, Kaholokula JK, Ratner R and Mau M: Ethnic differences in perinatal outcome of gestational diabetes mellitus. Diabetes Care 29: 2058-2063, 2006.

9. Malecki MT and Mlynarski W: Monogenic diabetes: implications for therapy of rare types of disease. Diabetes Obes Metab (In press). 
10. Lovejoy JC: The influence of dietary fat on insulin resistance. Curr Diab Rep 2: 435-440, 2002.

11. Hu FB: Sedentary lifestyle and risk of obesity and type 2 diabetes. Lipids 38: 103-108, 2003.

12. Harris R, Donahue K, Rathore SS, Frame P, Woolf SH and Lohr KN: Screening adults for type 2 diabetes: a review of the evidence for the U.S. Preventive Services Task Force. Ann Intern Med 138: 215-229, 2003.

13. Waeber G, Thompson N, Nicod P and Bonny C: Transcriptional activation of the GLUT2 gene by the IPF-1/STF-1/IDX-1 homeobox factor. Mol Endocrinol 10: 1327-1334, 1996.

14. Watada H, Kajimoto Y, Umayahara Y, Matsuoka T, Kaneto H, Fujitani Y, Kamada T, Kawamori R and Yamasaki Y: The human glucokinase gene beta-cell-type promoter: an essential role of insulin promoter factor $1 / \mathrm{PDX}-1$ in its activation in HITT15 cells. Diabetes 45: 1478-1488, 1996.

15. Bell GI and Polonsky KS: Diabetes mellitus and genetically programmed defects in beta-cell function. Nature 414: 788-791, 2001.

16. Stoffel M, Stein R, Wright CV, Espinosa R III, Le Beau MM and Bell GI: Localization of human homeodomain transcription factor insulin promoter factor 1 (IPF1) to chromosome band 13q12.1. Genomics 28: 125-126, 1995 .

17. Hani EH, Stoffers DA, Chevre JC, Durand E, Stanojevic V, Dina C, Habener JF and Froguel P: Defective mutations in the insulin promoter factor-1 (IPF-1) gene in late-onset type 2 diabetes mellitus. J Clin Invest 104: R41-R48, 1999

18. Hansen L, Urioste S, Petersen HV, Jensen JN, Eiberg H, Barbetti F, Serup P, Hansen T and Pedersen O: Missense mutations in the human insulin promoter factor-1 gene and their relation to maturity-onset diabetes of the young and late-onset type 2 diabetes mellitus in caucasians. J Clin Endocrinol Metab 85: $1323-1326,2000$

19. Ashizawa S, Brunicardi FC and Wang XP: PDX-1 and the pancreas. Pancreas 28: 109-120, 2004.

20. Shih DQ and Stoffel M: Molecular etiologies of MODY and other early-onset forms of diabetes. Curr Diab Rep 2: 125-134, 2002.

21. Stoffers DA, Ferrer J, Clarke WL and Habener JF: Early-onset type-II diabetes mellitus (MODY4) linked to IPF1. Nat Genet 17: $138-139,1997$.

22. Kaneto H, Miyatsuka T, Shiraiwa T, Yamamoto K, Kato K, Fujitani Y and Matsuoka TA: Crucial role of PDX-1 in pancreas development, beta-cell differentiation, and induction of surrogate beta-cells. Curr Med Chem 14: 1745-1752, 2007.

23. Stoffers DA, Zinkin NT, Stanojevic V, Clarke WL and Habener JF: Pancreatic agenesis attributable to a single nucleotide deletion in the human IPF1 gene coding sequence. Nat Genet 15: 106-110, 1997 .

24. Jonsson J, Ahlgren U, Edlund T and Edlund H: IPF1, a homeodomain protein with a dual function in pancreas development. Int J Dev Biol 39: 789-798, 1995

25. Jonsson J, Carlsson L, Edlund T and Edlund H: Insulinpromoter-factor 1 is required for pancreas development in mice. Nature 371: 606-609, 1994.

26. Ahlgren U, Jonsson J, Jonsson L, Simu K and Edlund H: Betacell-specific inactivation of the mouse Ipf1/Pdx 1 gene results in loss of the beta-cell phenotype and maturity onset diabetes. Genes Dev 12: 1763-1768, 1998.

27. Verwest AM, Poelman M, Dinjens WN, Batstra MR, Oostra BA Lequin $\mathrm{MH}$, Larsson LI, Aanstoot HJ, Bruining GJ and De Krijger RR: Absence of a PDX-1 mutation and normal gastroduodenal immunohistology in a child with pancreatic agenesis. Virchows Arch 437: 680-684, 2000.

28. Ferber S, Halkin A, Cohen H, Ber I, Einav Y, Goldberg I, Barshack I, Seijffers R, Kopolovic J, Kaiser N and Karasik A: Pancreatic and duodenal homeobox gene 1 induces expression of insulin genes in liver and ameliorates streptozotocin-induced hyperglycemia. Nat Med 6: 568-572, 2000.

29. Li Y, Zhang R, Qiao H, Zhang H, Wang Y, Yuan H, Liu Q, Liu D, Chen L and Pei X: Generation of insulin-producing cells from PDX-1 gene-modified human mesenchymal stem cells. J Cell Physiol 211: 36-44, 2007.

30. Wang AY, Ehrhardt A, Xu H and Kay MA: Adenovirus transduction is required for the correction of diabetes using Pdx-1 or Neurogenin-3 in the liver. Mol Ther 15: 255-263, 2007.

31. Ber I, Shternhall K, Perl S, Ohanuna Z, Goldberg I, Barshack I, Venisti-Zarum L, Meivar-Levy I and Ferber S: Functional, persistent, and extended liver to pancreas transdifferentiation. J Biol Chem 278: 31950-31957, 2003.
32. Kojima H, Fujimiya M, Matsumura K, Younan P, Imaeda H, Maeda $M$ and Chan L: NeuroD-betacellulin gene therapy induces islet neogenesis in the liver and reverses diabetes in mice. Nat Med 9: 596-603, 2003

33. Hori Y, Rulifson IC, Tsai BC, Heit JJ, Cahoy JD and Kim SK: Growth inhibitors promote differentiation of insulin-producing tissue from embryonic stem cells. Proc Natl Acad Sci USA 99: 16105-16110, 2002.

34. Lumelsky N, Blondel O, Laeng P, Velasco I, Ravin R and McKay R: Differentiation of embryonic stem cells to insulinsecreting structures similar to pancreatic islets. Science 292 1389-1394, 2001

35. Yoshida S, Kajimoto Y, Yasuda T, Watada H, Fujitani Y, Kosaka H, Gotow T, Miyatsuka T, Umayahara Y, Yamasaki Y and Hori M: PDX-1 induces differentiation of intestinal epithelioid IEC-6 into insulin-producing cells. Diabetes 51: 2505-2513, 2002.

36. Tang DQ, Cao LZ, Burkhardt BR, Xia CQ, Litherland SA, Atkinson MA and Yang LJ: In vivo and in vitro characterization of insulin-producing cells obtained from murine bone marrow. Diabetes 53: 1721-1732, 2004.

37. Kojima H, Nakamura T, Fujita Y, Kishi A, Fujimiya M, Yamada S, Kudo M, Nishio Y, Maegawa H, Haneda M, Yasuda H, Kojima I, Seno M, Wong NC, Kikkawa R and Kashiwagi A: Combined expression of pancreatic duodenal homeobox 1 and islet factor 1 induces immature enterocytes to produce insulin. Diabetes 51: 1398-1408, 2002.

38. Ohneda K, Mirmira RG, Wang J, Johnson JD and German MS The homeodomain of PDX-1 mediates multiple protein-protein interactions in the formation of a transcriptional activation complex on the insulin promoter. Mol Cell Biol 20: 900-911, 2000.

39. Qiu Y, Guo M, Huang S and Stein R: Insulin gene transcription is mediated by interactions between the p300 coactivator and PDX-1, BETA2, and E47. Mol Cell Biol 22: 412-420, 2002.

40. Thomas MK, Yao KM, Tenser MS, Wong GG and Habener JF: Bridge-1, a novel PDZ-domain coactivator of E2A-mediated regulation of insulin gene transcription. Mol Cell Biol 19: 8492-8504, 1999

41. Hay CW and Docherty K: Comparative analysis of insulin gene promoters: implications for diabetes research. Diabetes 55: 3201-3213, 2006.

42. Strahl BD and Allis CD: The language of covalent histone modifications. Nature 403: 41-45, 2000.

43. Stanojevic V, Habener JF and Thomas MK: Pancreas duodenum homeobox-1 transcriptional activation requires interactions with p300. Endocrinology 145: 2918-2928, 2004.

44. Mosley AL, Corbett JA and Ozcan S: Glucose regulation of insulin gene expression requires the recruitment of p300 by the beta-cell-specific transcription factor Pdx-1. Mol Endocrinol 18: 2279-2290, 2004

45. Wu H, Macfarlane WM, Tadayyon M, Arch JR, James RF and Docherty K: Insulin stimulates pancreatic-duodenal homoeobox factor-1 (PDX1) DNA-binding activity and insulin promoter activity in pancreatic beta cells. Biochem J 344: 813-818, 1999.

46. Johnson JD, Bernal-Mizrachi E, Alejandro EU, Han Z, Kalynyak TB, Li H, Beith JL, Gross J, Warnock GL, Townsend RR, Permutt MA and Polonsky KS: Insulin protects islets from apoptosis via $\mathrm{Pdx} 1$ and specific changes in the human islet proteome. Proc Natl Acad Sci USA 103: 19575-19580, 2006

47. Flock G, Cao X and Drucker DJ: Pdx-1 is not sufficient for repression of proglucagon gene transcription in islet or enteroendocrine cells. Endocrinology 146: 441-449, 2005.

48. Cockburn BN, Bermano G, Boodram LL, Teelucksingh S, Tsuchiya T, Mahabir D, Allan AB, Stein R, Docherty K and Bell GI: Insulin promoter factor-1 mutations and diabetes in Trinidad: identification of a novel diabetes-associated mutation (E224K) in an Indo-Trinidadian family. J Clin Endocrinol Metab 89: 971-978, 2004.

49. Lu M, Miller C and Habener JF: Functional regions of the homeodomain protein IDX-1 required for transactivation of the rat somatostatin gene. Endocrinology 137: 2959-2967, 1996.

50. Peers B, Sharma S, Johnson T, Kamps M and Montminy M The pancreatic islet factor STF-1 binds cooperatively with $\mathrm{Pbx}$ to a regulatory element in the somatostatin promoter: importance of the FPWMK motif and of the homeodomain. Mol Cell Biol 15: 7091-7097, 1995.

51. Liu Y, MacDonald RJ and Swift GH: DNA binding and transcriptional activation by a PDX1.PBX1b.MEIS2b trimer and cooperation with a pancreas-specific basic helix-loop-helix complex. J Biol Chem 276: 17985-17993, 2001. 
52. Goudet G, Delhalle S, Biemar F, Martial JA and Peers B: Functional and cooperative interactions between the homeodomain PDX1, Pbx, and Prep1 factors on the somatostatin promoter. J Biol Chem 274: 4067-4073, 1999.

53. Dutta S, Gannon M, Peers B, Wright C, Bonner-Weir S and Montminy M: PDX:PBX complexes are required for normal proliferation of pancreatic cells during development. Proc Natl Acad Sci USA 98: 1065-1070, 2001.

54. Noguchi H, Kaneto H, Weir GC and Bonner-Weir S: PDX-1 protein containing its own antennapedia-like protein transduction domain can transduce pancreatic duct and islet cells. Diabetes 52: 1732-1737, 2003.

55. Moede T, Leibiger B, Pour HG, Berggren P and Leibiger IB: Identification of a nuclear localization signal, RRMKWKK, in the homeodomain transcription factor PDX-1. FEBS Lett 461: 229-234, 1999.

56. Hessabi B, Ziegler P, Schmidt I, Hessabi C and Walther R: The nuclear localization signal (NLS) of PDX-1 is part of the homeodomain and represents a novel type of NLS. Eur J Biochem 263: 170-177, 1999.

57. Macfarlane WM, McKinnon CM, Felton-Edkins ZA, Cragg H, James RF and Docherty K: Glucose stimulates translocation of the homeodomain transcription factor PDX1 from the cytoplasm to the nucleus in pancreatic beta-cells. J Biol Chem 274: 1011-1016, 1999.

58. Macfarlane WM, Smith SB, James RF, Clifton AD, Doza YN, Cohen P and Docherty K: The p38/reactivating kinase mitogenactivated protein kinase cascade mediates the activation of the transcription factor insulin upstream factor 1 and insulin gene transcription by high glucose in pancreatic beta-cells. J Biol Chem 272: 20936-20944, 1997.
59. Rafiq I, da Silva Xavier G, Hooper S and Rutter GA: Glucosestimulated preproinsulin gene expression and nuclear translocation of pancreatic duodenum homeobox-1 require activation of phosphatidylinositol 3-kinase but not p38 MAPK/SAPK2. J Biol Chem 275: 15977-15984, 2000.

60. Kishi A, Nakamura T, Nishio Y, Maegawa $\mathrm{H}$ and Kashiwagi A: Sumoylation of Pdx1 is associated with its nuclear localization and insulin gene activation. Am J Physiol Endocrinol Metab 284: E830-E840, 2003.

61. Boucher MJ, Selander L, Carlsson L and Edlund H: Phosphorylation marks IPF1/PDX1 protein for degradation by glycogen synthase kinase 3-dependent mechanisms. J Biol Chem 281: 6395-6403, 2006.

62. Gao Y, Miyazaki J and Hart GW: The transcription factor PDX-1 is post-translationally modified by $\mathrm{O}$-linked $\mathrm{N}$-acetylglucosamine and this modification is correlated with its DNA binding activity and insulin secretion in min6 beta-cells. Arch Biochem Biophys 415: 155-163, 2003.

63. Lebrun P, Montminy MR and Van OE: Regulation of the pancreatic duodenal homeobox-1 protein by DNA-dependent protein kinase. J Biol Chem 280: 38203-38210, 2005.

64. An R, da Silva Xavier G, Hao HX, Semplici F, Rutter J and Rutter GA: Regulation by Per-Arnt-Sim (PAS) kinase of pancreatic duodenal homeobox-1 nuclear import in pancreatic beta-cells. Biochem Soc Trans 34: 791-793, 2006. 